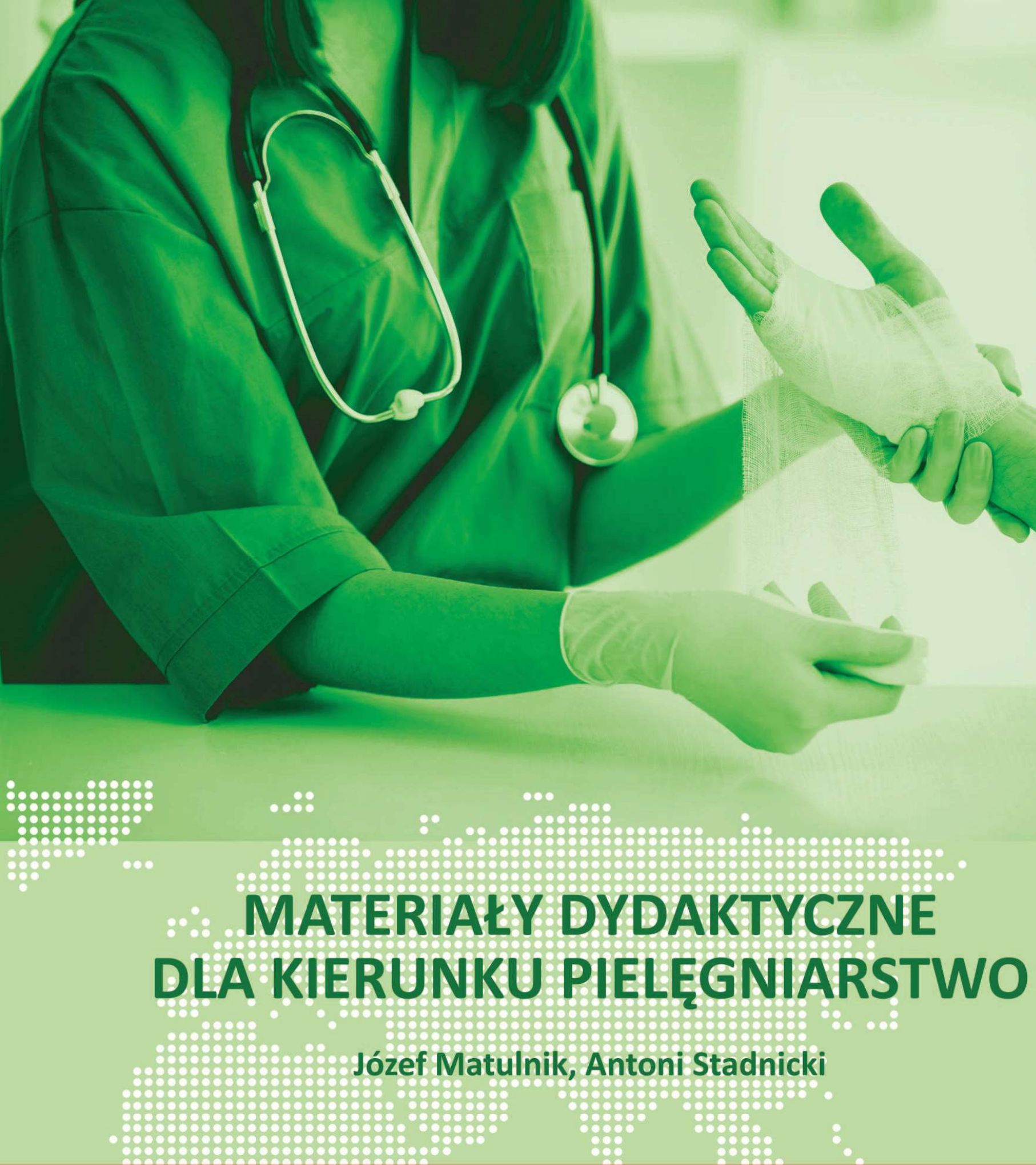

8.80800888:88 -

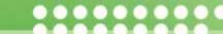
0000000

$00 \mathrm{c}$ भी०00009

000

9898998989989 990

200000000000000000000000000000000000

$\because$ MATERIAŁY DYDAKTYCZNE

DLA KIERUNKU PIELĘGNIARSTWO

9090809

进

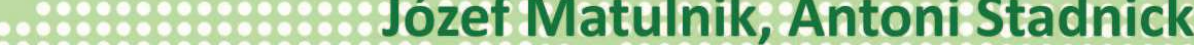

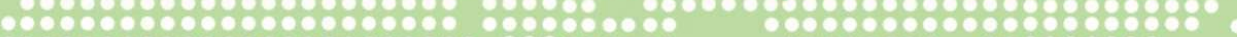
$00000000 \quad 00000000$

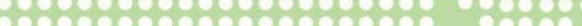
00000000000000000000000000000

Fundusze Europejskie Wiedza Edukacja Rozwój

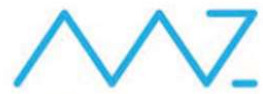

Ministerstwo Zdrowia
Rzeczpospolita Polska
Unia Europejska

Europejski Fundusz Spoteczny 


\title{
Materiały dydaktyczne dla kierunku Pielęgniarstwo
}

\author{
Leczenie ran \\ Pielęgnowanie pacjenta z cukrzycą \\ Pielęgnowanie pacjenta z POChP \\ Żywienie dojelitowe i pozajelitowe \\ Leczenie bólu przewlekłego
}

Częstochowa 2019
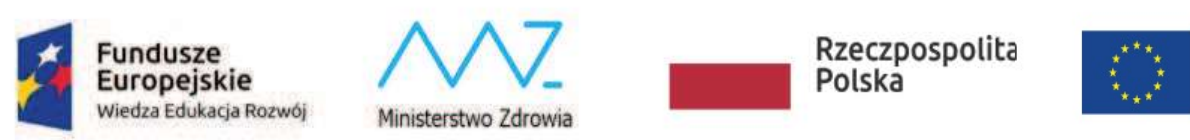

Unia Europejska

Europejski Fundusz Spoteczny

Projekt nr POWR.05.05.00-00-0006/18 pt. " Wzbogacenie jakości kształcenia wyższego na kierunku pielęgniarstwo w Akademii Polonijnej w Częstochowie" realizowany w ramach Programu Operacyjnego Wiedza Edukacja Rozwój, Działanie 5.5 Rozwój usług pielęgniarskich 


\section{REDAKCJA NAUKOWA}

Prof. dr. hab. Józef Matulnik

Prof. dr hab. n. med. Antoni Stadnicki

\section{RECENZENT}

dr n. med. Georges Tebug Kamtoh

Publikacja opracowana w ramach projektu nr POWR.05.05.00-00-0006/18 pt. " Wzbogacenie jakości kształcenia wyższego na kierunku pielęgniarstwo w Akademii Polonijnej w Częstochowie" realizowanego w ramach Programu Operacyjnego Wiedza Edukacja Rozwój, Działanie 5.5 Rozwój usług pielęgniarskich

Nakład: 110 egzemplarzy

ISBN: 978-83-7542-189-7

DOI: $10.32782 / 978-83-7542-189-7$

SERIA WYDAWNICZA: HED/03/02 ZDROWIE, ŚRODOWISKO, ROZWÓJ

(C) Copyright by Akademia Polonijna w Częstochowie

Wydawnictwo Akademii Polonijnej „Educator”

ul. Pułaskiego 4/6 42-200 CZĘSTOCHOWA

email:wydawnictwo@ap.edu.pl 